\title{
Achieving treatment goals for schoolchildren with asthma
}

\author{
E J Fillmore, N Jones, J M Blankson
}

\begin{abstract}
Objectives-To identify problems in managing asthmatic children in school, which if dealt with would help reduce absenteeism and improve participation in school activities.

Design-A survey by questionnaire to headteachers.

Setting-Schools in Merthyr and Rhondda Cynon Taff, South Wales.

Subject-Asthmatic schoolchildren in areas studied.

Main outcome measures-Facilities in schools to manage asthma, headteachers' perceptions of knowledge of asthma management by teachers, possession of written policies, and desire for further training.

Results-There are 216 schools in the area studied, with 55166 schoolchildren. A total of $191(88 \%)$ headteachers returned the completed questionnaire. Five hundred and twenty seven (17\%) children were reported absent from school during one term because of asthma, with an average of nine days of schooling lost per asthmatic child per term (range 2-16 days).

Only $76(40 \%)$ schools allowed children to be responsible for their inhalers, and 12 $(6 \%)$ schools required parents to administer inhalers. In $115(60 \%)$ schools, headteachers believed their staff were familiar with the management of asthma. A total of 174 (91\%) headteachers expressed interest in further training.

Conclusion-This study highlights the need to train teachers and provide an agreed joint education and health policy on managing asthma in school.

(Arch Dis Child 1997;77:420-422)
\end{abstract}

Keywords: asthma; schools; policy; treatment goals

Asthma continues to be the most common single chronic disease among schoolchildren. ${ }^{1} \mathrm{~A}$ study of children in South Wales between 1973 and 1989 showed that prevalence is probably still increasing. ${ }^{2}$ In Croydon, England, in 1994, Anderson et al reported an increase in prevalence over 13 years from $4 \%$ to $13 \%$ of children reporting wheeze in the previous 12 months.

In schoolchildren, the index of morbidity is inferred from school absenteeism due to asthma ill health. Figures for absenteeism are unacceptably high, as reported by Freudenberg et $a l .{ }^{4}$ These findings were confirmed in a report by Speight et al, which showed that 36\% of asthmatic children had been absent from school for more than 50 days in one year due to wheeze. ${ }^{5}$

The goal of general asthma management is to achieve normal health and activity. High absenteeism is detrimental to educational needs and full participation in school activities. In attempting to prevent such morbidity it has been suggested that educational authorities must be involved in the setting up of protocols for management of asthmatic children in schools. $^{5}$

Unfortunately, the lack of school nurses has meant that most teachers have been reluctant to participate in such management, primarily because of lack of knowledge of asthma and fear of supervising or giving drugs to children in school. ${ }^{6}$

This study was designed to identify problems in managing asthmatic children in school, which if corrected, would help reduce school absenteeism and promote complete participation in school activites.

\section{Method}

We gave a questionnaire to each headteacher of all schools in the Merthyr and Rhondda Cynon Taff area. There are 216 schools, with 12 nursery (3-5 years), 172 primary (3-11 years), 27 secondary (11-19 years), and five special needs schools (3-19 years). Questions were designed to cover the identification of children known to have asthma, facilities in school to manage asthma, the headteachers' perceptions of how well teachers understood asthma management, the possession of written policies, and the need for further training. The study had the full support of the two local directors of education and the medical director of North Glamorgan NHS Trust. Ethical approval was given.

\section{Results}

The total number of schools in the area studied was 216, with 55166 school age children. Altogether, $191(88 \%)$ schools returned the completed questionnaire. Of the 25 (12\%) schools which failed to return the questionnaire, 12 reported not receiving it, one private school refused to participate, and 12 gave no reason. Data were analysed as a whole, and then stratified into primary and nursery (3-11 years), secondary (11-19 years), and special needs (3-19 years) (table 1).

Five hundred and twenty seven children were reported to have been absent from school during the summer term due to asthma, with an average of nine days of schooling lost per asthmatic child per term (range 2-16 days). 


\begin{tabular}{|c|c|c|c|}
\hline Question & $\begin{array}{l}\text { Primary schools } \\
\text { (3-11 years) } \\
\text { YES (\%) }\end{array}$ & $\begin{array}{l}\text { Secondary schools } \\
\text { (11-19 years) } \\
\text { YES (\%) }\end{array}$ & $\begin{array}{l}\text { Special needs schools } \\
\text { (3-19 years) } \\
\text { YES (\%) }\end{array}$ \\
\hline 1. Does the school have a written asthma policy? & $40(31)$ & $5(26)$ & $3(60)$ \\
\hline 2. Are children allowed to bring inhalers to school? & $167(100)$ & $19(100)$ & $5(100)$ \\
\hline 3. Does the school collect inhalers? & $108(65)$ & $2(11)$ & $5(100)$ \\
\hline Are the inhalers locked away? & $2(2)$ & 0 & 0 \\
\hline $\begin{array}{l}\text { 4. Do parents have to come to school to give inhalers to their } \\
\text { children? }\end{array}$ & $12(7)$ & 0 & 0 \\
\hline $\begin{array}{l}\text { 5. Does the school have a designated nurse trained in } \\
\text { asthma? }\end{array}$ & $11(7)$ & $9(47)$ & $1(20)$ \\
\hline $\begin{array}{l}\text { 7. Does anyone know what to do for an acute asthma attack } \\
\text { 7. }\end{array}$ & $86(51)$ & $8(42)$ & $4(80)$ \\
\hline $\begin{array}{l}\text { before help arrives? } \\
\text { 8. Does the school have written instructions or posters on }\end{array}$ & $11(66)$ & $18(95)$ & $4(80)$ \\
\hline dealing with an acute asthma attack? & $64(38)$ & $7(37)$ & $2(40)$ \\
\hline $\begin{array}{l}\text { 9. Are staff familiar with various devices available to asthma } \\
\text { sufferers? }\end{array}$ & $110(66)$ & $4(21)$ & $1(20)$ \\
\hline $\begin{array}{l}\text { 10. Does the school have a device that can be used in an } \\
\text { emergency to overcome an acute attack? }\end{array}$ & $29(17)$ & $2(11)$ & 0 \\
\hline $\begin{array}{l}\text { 11. Is the school issued with cards or letters from the GP, } \\
\text { hospital, or parent stating the child's treatment? } \\
\text { 12. Would the school be interested in any future training }\end{array}$ & $13(8)$ & $5(26)$ & $5(100)$ \\
\hline sessions? & $154(92)$ & $17(89)$ & $3(60)$ \\
\hline
\end{tabular}

They represent $17 \%$ of the total reported as having asthma. However, 45 (24\%) schools were unable to give reasons for absenteeism as no specific record was kept of the causes of absenteeism.

Only $48(25 \%)$ schools had an asthma policy, and there was marked variability in policies disclosed to us. Some policies were derived from guidelines set out by the National Asthma Campaign, others followed guidelines from the local health authority, with adaptations for the individual school environment. Headteachers commented that the initiation of policies often came from a particular member of staff's interest or personal experience of asthma. Some policies consisted of a single page of clearly set out points on exacerbating factors, features, and treatment of an asthma attack. Other policies were more lengthy, dealing with asthma as well as the management of other chronic childhood diseases, such as epilepsy and diabetes.

All schools allowed inhalers to be brought in, but only $76(40 \%)$ schools allowed children to be responsible for their own inhalers. At two schools (both primary), inhalers were collected and locked away. Twelve (6\%) schools required parents to come to school to administer inhalers, should the need arise.

One hundred and eighteen (62\%) schools did not have posters or written instructions about dealing with asthma and 168 (88\%) schools did not have treatment cards from hospitals, general practitioners (GPs), or parents. Of the schools that held medical information on children with asthma, headteachers reported that the drug treatment doses and administration times were often unclear and not updated after a visit by the child to the GP or hospital specialist. A lack of communication from parents or carers regarding the health needs of their child, and the lack of a school nurse, were reported as the main causes of problems with upkeep of records.

Only $31(16 \%)$ schools had emergency equipment available for use in an acute attack of asthma. The questionnaire did not seek details of the type of equipment used. Only 21
(11\%) schools had a designated school nurse trained in asthma management. One hundred and seventy four (91\%) headteachers were interested in receiving further training in asthma management for their school staff.

\section{Discussion}

Our survey of headteachers' views of asthma in schools in the Merthyr and Rhondda Cynon Taff areas has provided useful information on how asthma is managed and highlighted areas of concern from educational and medical perspectives.

The number of children considered to have asthma by headteachers in this survey ranged from $0-25 \%$, with a mean of $6 \%$. This compares with a mean of $3 \%$ from a survey of headteachers of schools in Nottingham in $1987,{ }^{7}$ and $7 \%$ from a survey of headteachers of schools in Durham in $1994 .^{8}$ These two surveys used similar questions to those in our study and definitions used were the same.

There are difficulties, however, in identifying asthmatic children in schools, and prevalence cannot be ascertained by asking headteachers because schools do not keep accurate diagnostic registers. We believe that a diagnostic register should be kept by all schools, initiated and kept up to date by the school nurse, and available to staff for accurate identification of children with medical conditions.

We believe the true morbidity of asthma in the schools is underestimated as formal records of absenteeism because of asthma ill health were not always held and much absenteeism because of asthma exacerbation went unrecorded.

Children's medical records should be updated periodically and reasons for absenteeism documented. This would give a more accurate overview of the problems to be tackled and help school health planning.

Within the areas covered by our survey there are dwindling numbers of school nurses, and as they have less time to give to children with asthma, schools need a system of identification and treatment cards for asthmatic children. 
Although headteachers reported that advice has been given by the National Asthma Campaign and the National Union of Teachers, no policy has been devised in Wales, either on a principalitywide basis or within the local education authorities' areas, to deal with the problems and treatment of asthma in schools. We envisage that there will be different policies devised in each local education authority area, tailored to the needs of the local school population, with guidelines on development of policy coming from the departments of health and education, as well as bodies such as the National Asthma Campaign.

All school staff need training to deal with asthmatic children at school. Teachers' knowledge of drugs and devices and when to give inhaled treatment was perceived by headteachers to be reasonable, but posters or written instructions on asthma management were present in only a small percentage of schools. Only a small proportion of headteachers reported having a device for use in an emergency to overcome an acute asthma attack. However, the type of device was not detailed in the questionnaire. In this survey only $76(40 \%)$ schools allowed children to keep their inhalers with them. From previous surveys there is recognition that older children should be encouraged to take responsibility for their own medication as soon as is practically possible. ${ }^{910}$

The level of interest from headteachers for future training was high and comments reflected a desire for comprehensive training with periodic reinforcement. Above all, we believe that training would give school staff the necessary confidence to cope with asthmatic children.

We believe that cooperation between the central government's departments of health and education, as well as local health and education authorities, to tackle some of the problems revealed by this survey may help to improve the wellbeing of asthmatic children in school.

We would like to thank Miss Barbara Morgan for typing the manuscript.

1 Lee DA, Winslow NR, Speight ANP, Hey EN. Prevalence and spectrum of asthma in childhood. BMF 1983;286:1256-8

2 Burr ML, Butland BK, King S, Vaughan-Williams E. Changes in asthma prevalence: two surveys 15 years apart. Arch Dis Child 1989;64:1452-6.

3 Anderson HR, Butland BK, Strachan DP. Trends in prevalence and severity of childhood asthma. BMF 1994;308: $1600-4$

4 Freudenberg N, Feldman CH, Clark NM, Millman EJ, Valle I, Wasilewski Y. The impact of bronchial asthma on school attendance and performance. F School Health 1980; 50:522-6.

5 Speight ANP, Lee DA, Hey EN. Underdiagnosis and Speight ANP, Lee DA, Hey EN. Underdiagnosis and undertreatn

6 Bevis M, Taylor B. What do school teachers know about asthma? Arch Dis Child 1990;65:622-5.

7 Hill RA, Britton JR, Tattersfield AE. Management of asthma in schools. Arch Dis Child 1987;62:414-5.

8 Pugh E, Mansfield K, Clague H, Mattinson P. Children with asthma in schools: an opportunity for 'healthy alliances' between health and education authorities. Health Trends 1995;27:127-9.

9 Cover AF. Community campaign against asthma. Arch Dis Child 1984;59:449-52

10 Milner AD. Bronchodilators in childhood asthma. In: Clark TJH, Cochrane GM, eds. Bronchodilator therapy. Auckland: Adis Press, 1984:93-111. 